Supporting Information

\title{
Title: Co-Assembly of Photosystem II and ATPase as Artificial Chloroplast for Light-Driven ATP Synthesis
}

\section{Authors: Xiyun Feng, Yi Jia, Peng Cai, Jinbo Fei, Junbai Li*}

\begin{abstract}
Affiliation: Beijing National Laboratory for Molecular Sciences (BNLMS), CAS Key Lab of Colloid, Interface and Chemical Thermodynamics, Institute of Chemistry, Chinese Academy of Sciences, Beijing, 100190, China.

E-mail: jbli@iccas.ac.cn; Fax: +86 10 82612629; Tel: +86 1082614087
\end{abstract}

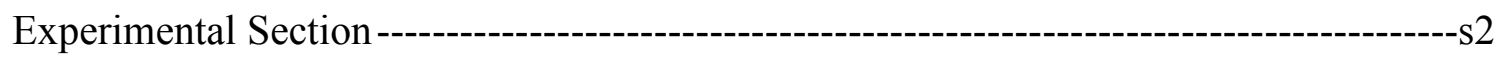

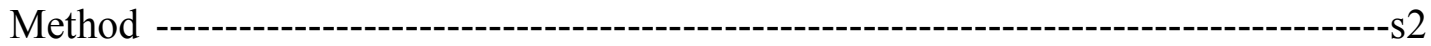

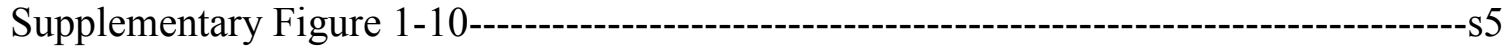

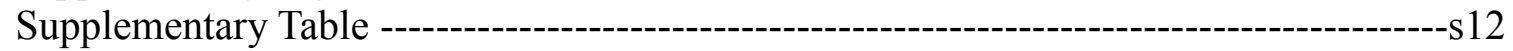

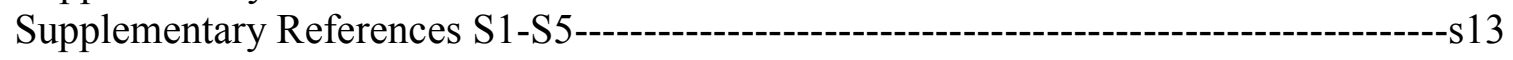




\section{Experimental Section}

\section{Method}

Isolation of $C F_{o} F_{1}$-ATPase and PSII. Active chloroplast $\mathrm{F}_{0} \mathrm{~F}_{1}$-ATPase was isolated and purified from spinach ${ }^{18}$. PSII-enriched membrane particles (BBY particles) were isolated from fresh spinach (Spinacia oleracea L.) purchased at a local market following a slightly modified protocol. ${ }^{\mathrm{s} 1}$ In detail, a total of $200 \mathrm{~g}$ spinach leaves were washed, keeping at $4{ }^{\circ} \mathrm{C}$ overnight, and then homogenized in a precooled blender, together with $500 \mathrm{~mL}$ of homogenization buffer B1 (0.4 M sucrose, $20 \mathrm{mM}$ Tricine $\pm \mathrm{NaOH}$ pH 7.8, $2 \mathrm{mM} \mathrm{MgCl}$, $40 \mathrm{mM} \mathrm{NaCl}, 2 \mathrm{mM} \mathrm{Vc}, 0.2 \% \mathrm{BSA})$. The leaf fragment was filtered through eight layers of cotton gauze, followed by centrifuging the filtrate at $6000 \mathrm{rpm}$ for $15 \mathrm{~min}$ to collect intact and broken chloroplasts. The precipitant was suspended in hypotonic buffer B2 $(20 \mathrm{mM}$ Tricine $\pm \mathrm{NaOH}$ pH 7.8, $5 \mathrm{mM} \mathrm{MgCl} 2,10 \mathrm{mM} \mathrm{NaCl}, 0.2 \% \mathrm{BSA}$ ) and stirred for $15 \mathrm{~min}$ to break the intact chloroplast. Following centrifugation at 7,000 $\mathrm{g}$ for $15 \mathrm{~min}$, the pellet was suspended in high ionic strength buffer B3 (0.4 M sucrose, $20 \mathrm{mM}$ MES $\pm \mathrm{NaOH}$ pH 6.5, $15 \mathrm{mM} \mathrm{NaCl}, 5 \mathrm{mM} \mathrm{MgCl}_{2}$ ). The chlorophyll concentration of thylakoid membranes suspension was determined and then adjusted to $2.5 \mathrm{mg} \mathrm{Chl} \mathrm{ml}^{-1}$ using buffer B3. Adding buffer B4 (0.4 M sucrose, $20 \mathrm{mM}$ MES $\pm \mathrm{NaOH}$ pH 6.5, $15 \mathrm{mM} \mathrm{NaCl}, 5 \mathrm{mM} \mathrm{MgCl} 2,10 \%$ TX-100) to the suspension slowly until the ratio of TX-100 to chlorophyll (w/w) is $20: 1$ and stirring for $10 \mathrm{~min}$, the solution was centrifuged at $10,000 \mathrm{~g}$ for $1 \mathrm{~min}$ to remove starch grains and debris, and then centrifuged at $35,000 \mathrm{~g}$ for $30 \mathrm{~min}$. The precipitate was washed till the supernatant is not green. The obtained BBY particles were suspended in stock solution B5 (0.4 M sucrose, $20 \mathrm{mM}$ MES $\pm \mathrm{NaOH}$ pH 6.5, $15 \mathrm{mM} \mathrm{NaCl}, 5 \mathrm{mM} \mathrm{MgCl} 2,1.5$ $\mathrm{M}$ betaine), and shock frozen in liquid nitrogen in $0.5 \mathrm{~mL}$ aliquots. The protein 
concentration was determined with the Bradford method. The fractions of $\mathrm{CF}_{0} \mathrm{~F}_{1}-\mathrm{ATPase}$ and BBY were analyzed by SDS-polyacrylamide gel electrophoresis on $12 \%$ polyacrylamide gels. $10 \mu \mathrm{L}$ solutions containing about $5-10 \mu$ g proteins were added to each line of the gel.

BBY particles were estimated by total Chl concentration assays in $80 \%$ acetone solution. ${ }^{\mathrm{s} 2}$ Concentrated stock solutions of isolated ATP synthase $\left(4 \mathrm{mg} \mathrm{mL}^{-1}\right)$, BBY $\left(5 \mathrm{mg} \mathrm{Chl} \mathrm{mL}{ }^{-1}\right)$ particles were kept frozen at $-80{ }^{\circ} \mathrm{C}$ until use.

Total chlorophyll $\left(\mu \mathrm{g} \mathrm{mL}^{-1}\right)=\left(8.02 \times\left(\mathrm{A}_{663}-\mathrm{A}_{720}\right)+20.21 \times\left(\mathrm{A}_{645}-\mathrm{A}_{720}\right)\right) \times$ sample dilution Mn-depleted PSII were prepared using hydroxylamine treatment ${ }^{\mathrm{s} 3}$ and Tris washing ${ }^{\mathrm{s} 4}$. In detail, PSII were suspended in freshly made $\mathrm{NH}_{2} \mathrm{OH}$ solution till the ratio is $1 / 4(\mathrm{v} / \mathrm{v})$, to final concentration of $5 \mathrm{mM} \mathrm{NH}_{2} \mathrm{OH}$ and $0.5 \mathrm{mg} \mathrm{Chl} \mathrm{ml}^{-1}$, and stirred in dark at $4{ }^{\circ} \mathrm{C}$ for 45 min. After centrifugation and washing cycles, the pellet was suspended in buffer B6 (20 mM Mes, $\mathrm{pH}$ 6.5, $2 \mathrm{mM} \mathrm{MgCl}_{2}, 10 \mathrm{mM} \mathrm{NaCl}$ and $0.4 \mathrm{M}$ sucrose). With Tris washing, PSII membranes were suspended in $0.8 \mathrm{M}$ Tris $\mathrm{pH} 8.8$ to about $0.1 \mathrm{mg} \mathrm{Chl} \mathrm{ml}^{-1}$, incubating in room light at $4{ }^{\circ} \mathrm{C}$ for $30 \mathrm{~min}$. After centrifugation, the pellet was washed and finally suspended in buffer B6.

Activity assays of PSII. The photochemical activity of PSII was determined by spectrophotometric assays of DCPIP oxidation and reduction ${ }^{35}$. PSII particles at concentration of $10 \mu \mathrm{g} \mathrm{Chl} \mathrm{mL} L^{-1}$ were mixed with buffer containing $50 \mu \mathrm{M}$ DPC (1, 5-diphenylcarbazide), $30 \mu \mathrm{M}$ DCPIP, $50 \mathrm{mM}$ MES and $50 \mathrm{mM} \mathrm{CaCl}_{2}$. Measurements were carried out on a SHIMADZU UV-2600 spectrophotometer to measure the light induced absorption changes at $600 \mathrm{~nm}$. DCPIP reduction rate of PSII is about $260 \mu \mathrm{mol}$ DCPIP (mg $\mathrm{Chl})^{-1} \mathrm{~h}^{-1}$. 
The action spectra for Chl a in PSII were measured using a home-built system that included a Xe lamp (HAMAMAZU, model E7536, P $150 \mathrm{~W}$ ) and a series of band pass filters (from $400 \mathrm{~nm}$ to $720 \mathrm{~nm}$ ). DCPIP measurement was carried out at a chlorophyll concentration of $10 \mu \mathrm{g} \mathrm{mL}^{-1}$. The spectral half-width of the filters was $10 \mathrm{~nm}$ and light intensity did not exceed $600 \mu \mathrm{W} \mathrm{cm}{ }^{-2}$. Correction was made so that equal incident quanta were given at each wavelength $^{39}$.

The oxygen evolution activity of PSII was measured with a Clark-type electrode at $25^{\circ} \mathrm{C}$ in a suspension containing $10 \mu \mathrm{g} \mathrm{ml}^{-1} \mathrm{Chl}, \quad 1 \quad \mathrm{mM} \quad \mathrm{K}_{3}\left[\mathrm{Fe}(\mathrm{CN})_{6}\right]$ with $0.2 \mathrm{mM}$ 2,6-dichlorobenzoquinone as electron accepter, $10 \mathrm{mM} \mathrm{NaCl}, 5 \mathrm{mM} \mathrm{CaCl}, 10 \mathrm{mM}$ $\mathrm{NaHCO}_{3}, 0.4 \mathrm{M}$ Sucrose, $25 \mathrm{mM}$ MES pH 6.0. ${ }^{\mathrm{s}}$

Activity assays of ATPase. Before reconstitution, the activity of ATPase was determined by measuring the rate of ATP hydrolysis $\left(0.6 \mu \mathrm{mol} \mathrm{Pi} \cdot \mathrm{mg} \mathrm{pro}^{-1} \cdot \mathrm{min}^{-1}\right)$. After reconstitution into the proteoliposome, the activity was determined by $\mathrm{pH}$-jump induced ATP synthesis ${ }^{\mathrm{s} 5}$. 


\section{Supplementary Figure}
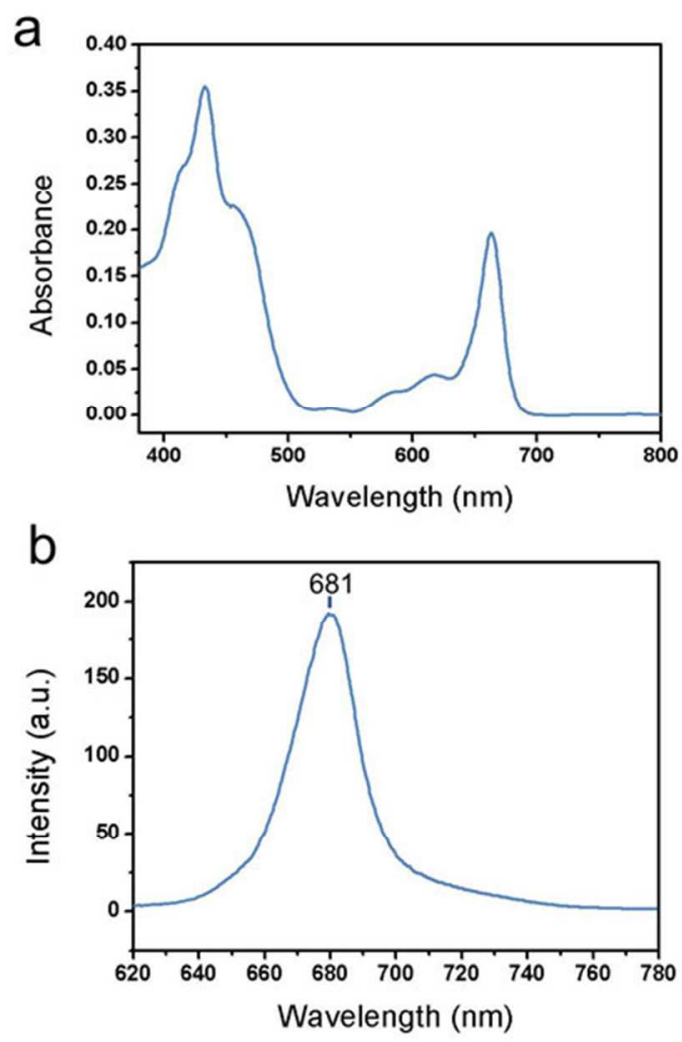

Supplementary Figure 1. Optical characterization of obtained PSII complex. (a) UV-visible absorption spectra and (b) fluorescence spectra (ex $438 \mathrm{~nm}$ ) of PSII at room temperature. Signals originates from the chlorophyll contained in PSII. 

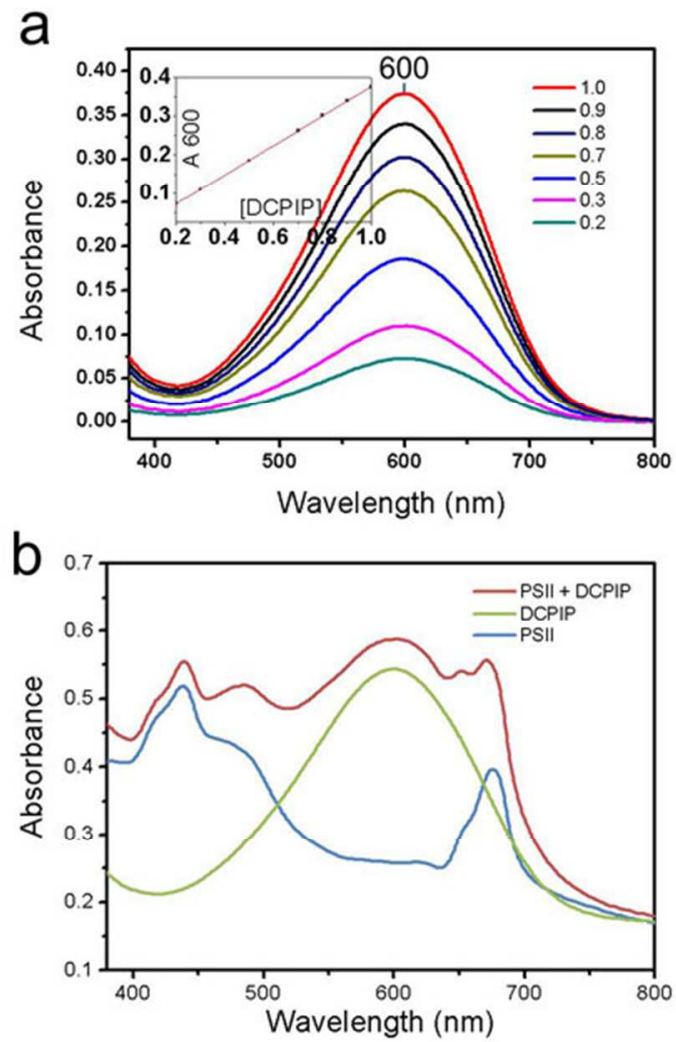

Supplementary Figure 2. Quantitative analysis of DCPIP. (a) UV-visible absorption spectra of DCPIP at different concentrations. Inset is the calibration plot of absorption versus concentration. (b) UV-visible absorption spectra of PSII, DCPIP, mixture of PSII and DCPIP. 


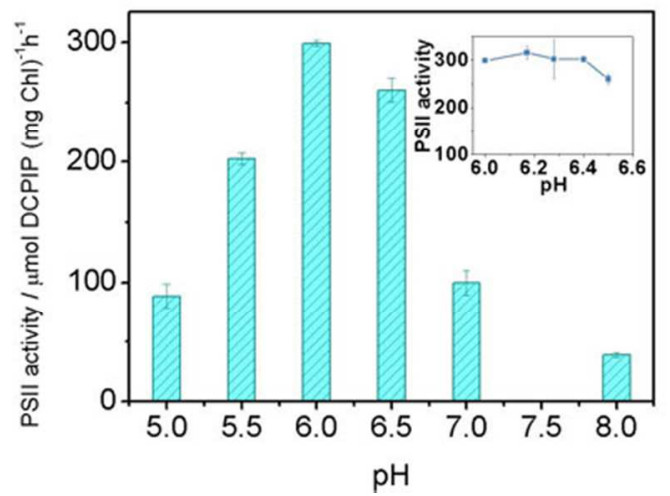

Supplementary Figure 3. The pH effect on the activity of PSII. Inset is the detailed $\mathrm{pH}$ effect between 6.0 and 6.5. All error bars refer to standard deviation $(n=6)$.

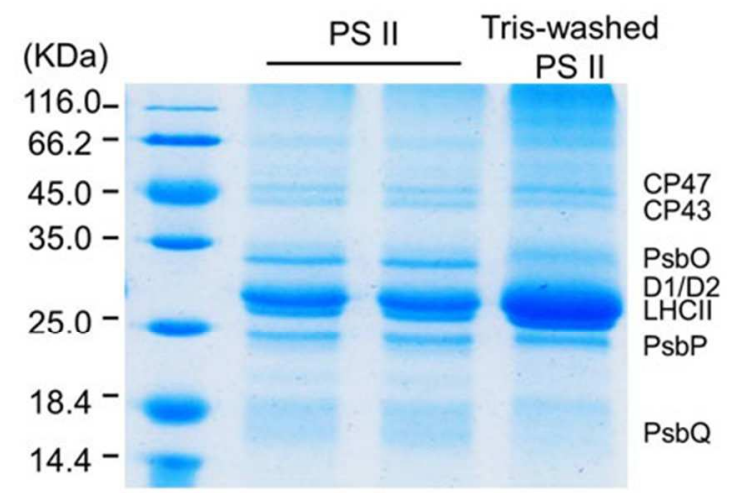

Supplementary Figure 4. SDS-PAGE of PSII and Mn-depleted PSII. Protein markers are labeled on the left. After Tris treatment, most of the PsbO (exterior polypeptides) were absent. 

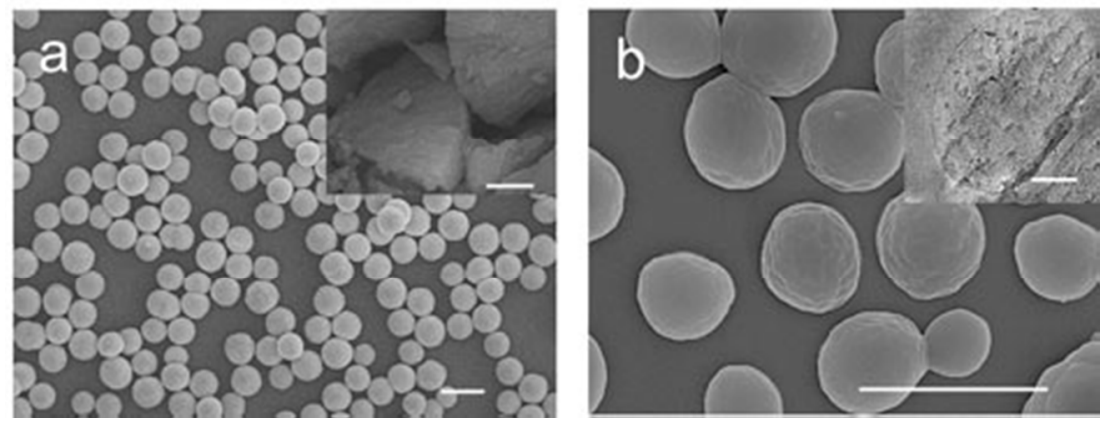

Supplementary Figure 5. Structure characterization and cross-sectional SEM images of PSII microspheres. (a) SEM image of PSII/BSA-loaded $\mathrm{CaCO}_{3}$ particles, the scale bar is 5 $\mu \mathrm{m}$. The inset is a cross-section image with higher magnification, the scale bar is $500 \mathrm{~nm}$. (b) PSII/BSA microspheres after the removal of $\mathrm{CaCO}_{3}$, the scale bar is $3 \mu \mathrm{m}$. The inset is a TEM cross-section image with higher magnification, the scale bar is $500 \mathrm{~nm}$.

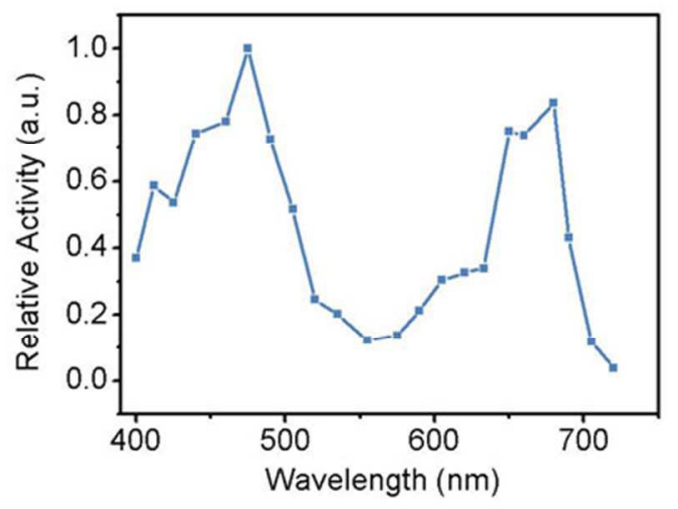

Supplementary Figure 6. Action spectra of PS II activities. DCPIP measurements were carried out in the presence of chlorophyll with a concentration of $10 \mu \mathrm{g} \mathrm{mL}^{-1}$. The spectral half-width of the band-pass filter was $10 \mathrm{~nm}$, and the light power density was below 600 $\mu \mathrm{W} \mathrm{cm} \mathrm{cm}^{-2}$ 


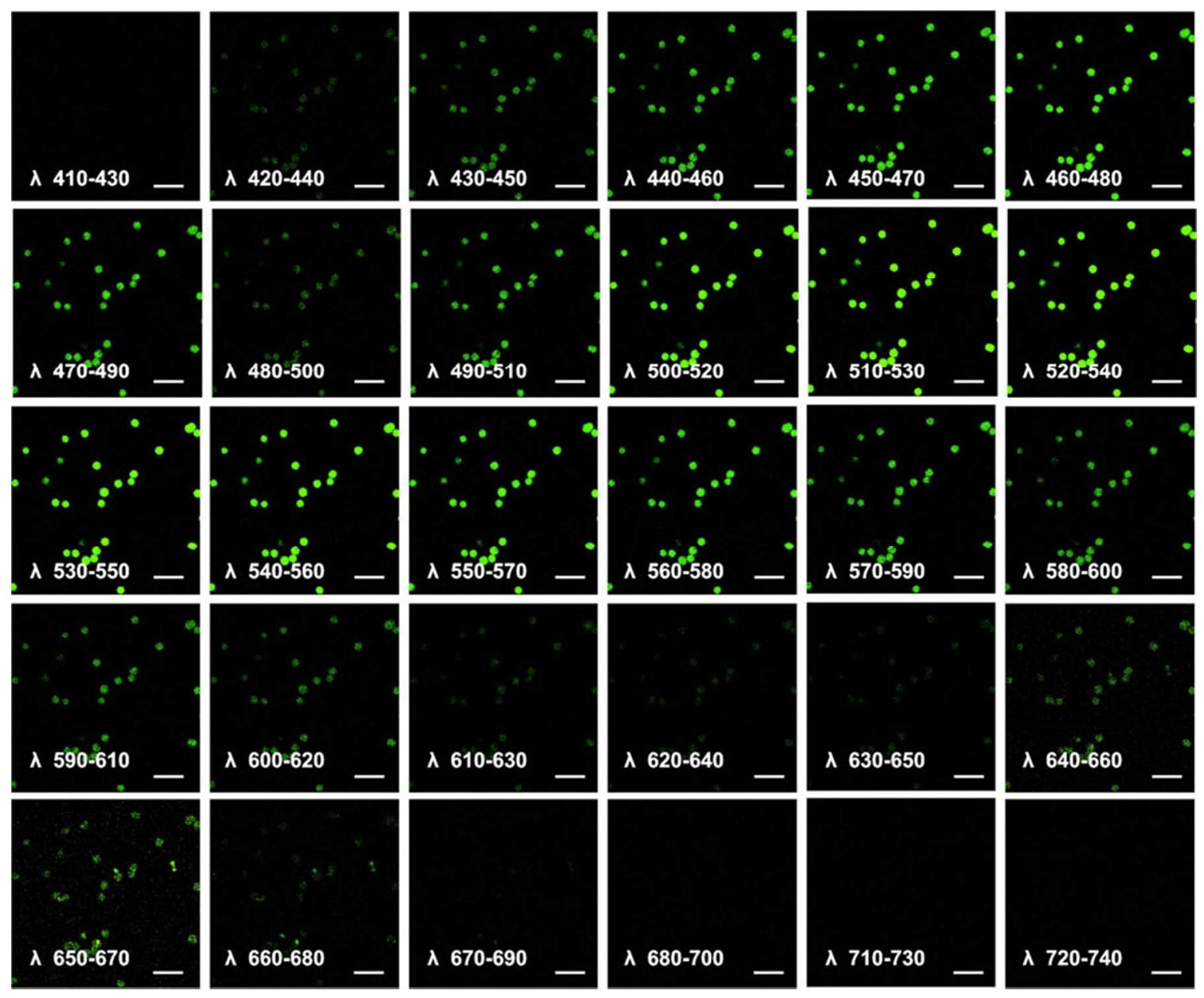

Supplementary Figure 7. CLSM images of lambda scan of PSII-based microspheres. The obvious fluorescence in the range of $640-680 \mathrm{~nm}$ reveals the feature of PSII in microspheres. The scale bars represent $10 \mu \mathrm{m}$. 


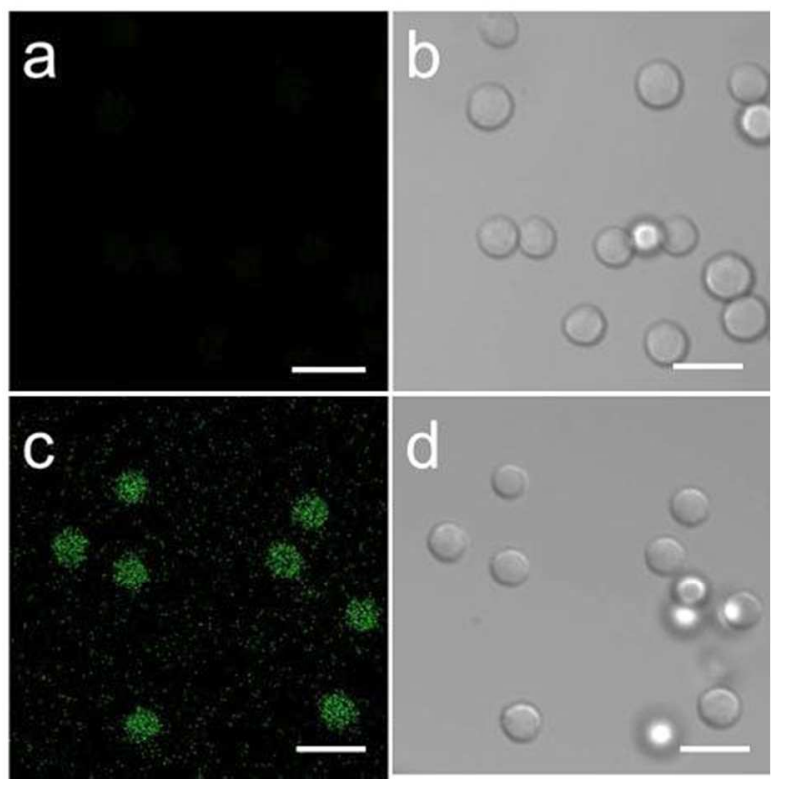

Supplementary Figure 8. CLSM images of BSA microsphere $(\mathbf{a}, \mathbf{b})$ and PSII microsphere (c, d) under the same condition (ex $405 \mathrm{~nm}$, fluorescent images obtained 660-680 nm). Comparing with PSII microsphere, BSA spheres did not show a fluorescent signal. The scale bars represent $5 \mu \mathrm{m}$. 
a

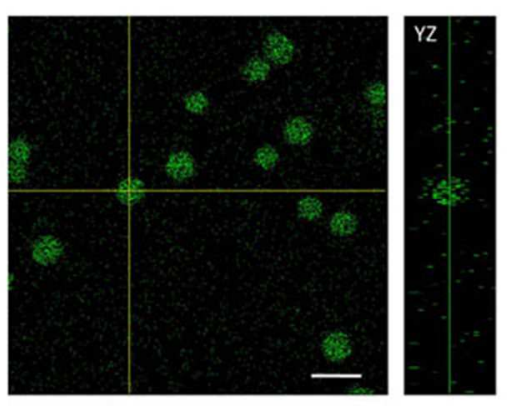

$x z$

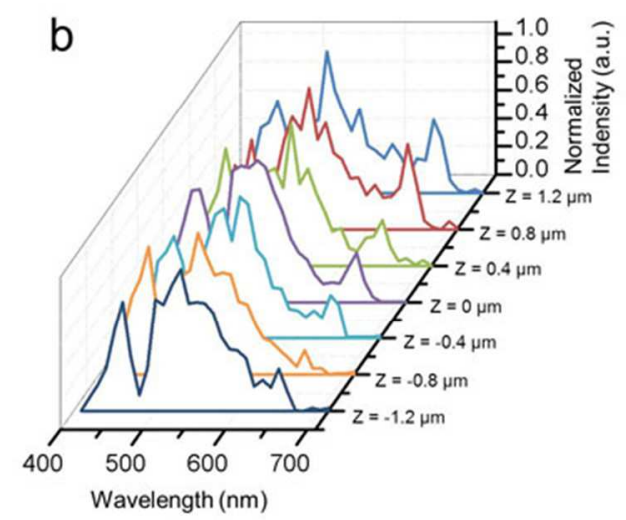

Supplementary Figure 9. Fluorescence spectra of microspheres at different sections obtained by CLSM lambda scanning. (a) A 3D CLSM image of PSII microsphere in the xz and yz planes. The two yellow lines correspond to xz (bottom) and yz (right) side view. (b) Fluorescence spectra of microspheres sections obtained by CLSM lambda scanning. 


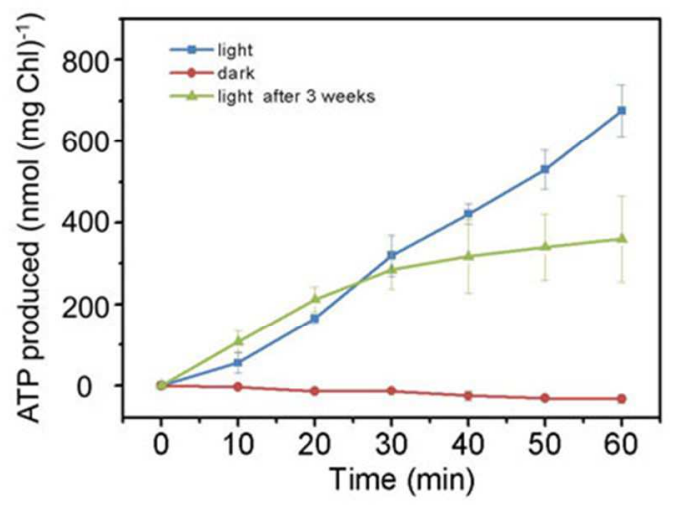

Supplementary Figure 10. ATP biosynthesis of ATPase-PSII microspheres after storage for 3 weeks at $4{ }^{\circ} \mathrm{C}$ in dark. All error bars refer to standard deviation $(n=3)$.

\section{Supplementary Table}

Supplementary Table 1 | Visible light driven oxygen-evolution activity of PSII complexes.

\begin{tabular}{|c|c|}
\hline PSII complexes & $\begin{array}{c}\text { Activity } \\
\left(\mu \mathrm{mol} \mathrm{O}{ }_{2}\left(\mathrm{mg} \mathrm{Chl}^{-1} \mathrm{~h}^{-1}\right)\right.\end{array}$ \\
\hline PSII & $580 \pm 22$ \\
\hline PSII + DCMU & 0 \\
\hline Tris-treat PSII & 0 \\
\hline $\mathrm{NH}_{2} \mathrm{OH}$-treat PSII & 0 \\
\hline PSII sphere & $230 \pm 15$ \\
\hline PSII-ATPase microsphere & $206 \pm 17$ \\
\hline
\end{tabular}




\section{Supplementary References}

[S1] a) Berthold D. A., Babcock G. T., Yocum C. F., A Highly Resolved, Oxygen-Evolving Photosystem II Preparation from Spinach Thylakoid Membranes: EPR and Electron-Transport Properties. Febs Lett. 1981, 134, 231-234; b) Hankamer B., Nield J., Zheleva D., Boekema E., Jansson S., Barber J., Isolation and Biochemical Characterization of Monomeric and Dimeric Photosystem II Complexes from Spinach and Their Relevance to the Organisation of Photosystem II in vivo. Eur.J. Biochem. 1997, 243, 422-429; c) Wang Z. G., Xu T. H., Liu C., Yang C. H., Fast Isolation of Highly Active Photosystem II Core Complexes from Spinach. J. Integr. Plant Biol. 2010, 52, 793-800.

[S2] Arnon D. I., Copper Enzymes in Isolated Chloroplasts Polyphenoloxidase in beta-Vulgaris. Plant Physiol. 1949, 24, 1-15.

[S3] Tamura N., Cheniae G., Photoactivation of the Water-Oxidizing Complex in Photosystem II Membranes Depleted of Mn and Extrinsic Proteins. I. Biochemical and Kinetic Characterization. Biochim. Biophys. Acta, Bioenerg. 1987, 890, 179-194.

[S4] Ahlbrink R., Semin B. K., Mulkidjanian A. Y., Junge W., Photosystem II of Peas: Effects of Added Divalent Cations of $\mathrm{Mn}, \mathrm{Fe}, \mathrm{Mg}$, and $\mathrm{Ca}$ on Two Kinetic Components of P-680(+) Reduction in Mn-Depleted Core Particles. Biochim. Biophys. Acta, Bioenerg. 2001, 1506, 117-126.

[S5] Merth B. V., Fromme R., Wang M., Fromme P., Crystallization of the $\mathrm{c}_{14}$-Rotor of the Chloroplast ATP Synthase Reveals That It Contains Pigments. Biochim. Biophys. Acta, Bioenerg. 2008, 1777, 605-612. 